\title{
INDIRECT IMMUNOFLUORESCENCE TEST IN NEW WORLD LEISHMANIASIS: SEROLOGICAL AND CLINICAL RELATIONSHIP
}

\author{
SERGIO C. F. MENDONÇA, WILSON J. S. SOUZA, MARISE P. NUNES, \\ MAURO C. A. MARZOCHI \& SERGIO G. COUTINHO \\ Instituto Oswaldo Cruz, Departamento de Protozoologia \\ Caixa Postal 926, 20001 Rio de Janeiro, RJ, Brasil
}

The indirect immunofluorescence test (IF) for anti-Leishmania antibodies (IgG and IgM) was performed with sera form the following groups of individuals: 214 cutaneous leishmaniasis patients, 28 healthy subjects with positive Montenegro's skin test (MST), 29 healthy subjects with negative MST and 16 visceral leishmaniasis patients. The first four groups came from a suburban area of Rio de Janeiro (Jacarepagua) where cutaneous leishmaniasis caused by Leishmania braziliensis braziliensis is endemic.

It was observed that IF-IgM titers were significantly higher amongst the cutaneous leishmaniasis patients with less than four months of disease as compared to those with longer periods and that IF.IgG titers were significantly higher in patients with multiple lesions as compared to those with single lesions. The visceral leishmaniasis patients had IF-IgG titers significantly higher than those from cutaneous leishmaniasis patients.

A group of 28 individuals selected amongst the 214 cutaneous leishmaniasis patients had their IF-titers (IgG and IgM) compared to those of the two control groups of healthy subjects from the endemic area, respectively with positive and negative MST. Significantly higher titers of IF-IgG and IF-IgM were found in the group with active disease. The same group of patients showed IF-IgG titers significantly lower at the end of the antimonial therapy than those observed during this tratment.

Key words: American leishmaniasis - serology - immunofluorescence

American cutaneous leishmaniasis (ACL) is endemic in the area of Jacarepaguá, a suburb of Rio de Janeiro. This situation has prevailed for a long time (D'Utra e Silva, 1915), with the disease occurring in human subjects and in dogs (Coutinho et al., 1985; Pirmez et al., 1988). The parasites isolated from both human and canine cases in the area have invariably been characterized as Leishmania braziliensis braziliensis (L. b. b.), using biochemical and immunological methods (Lopes et al., 1984; Grimaldi et al., 1987). These observations sug. gest that this subspecies is the only one which is actually being transmitted in that area.

Use of the indirect immunofluorescence test (IF) has been proposed for diagnosis, (Oddo

This investigation received support from the UNDP/ World Bank/WHO Special Programme for Research and Training in Tropical Diseases and FINEP.

Received February 10, 1988.

Accepted June 15, 1988.
\& Cascio, 1963) and for monitoring the cure (Chiari et al., 1973b) of ACL. A number of authors have already observed the decline in the levels of specific circulating antibodies after antimonial therapy (Bittencourt, et al., 1968; Souza et al., 1982) or even after spontaneous healing (Marzochi et al., 1980). It has been suggested that the persistence of positive titers after treatment should be ascribed to maintenance of the parasitic infection, which might worsen prognosis in this disease, whose secondary mucosal lesions are the most serious clinical manifestation.

The purpose of this study was to find out correlation between clinical features of leishmanial infections with emphasis on cutaneous leishmaniasis caused by $L . b$. braziliensis and serological aspects of the humoral immune response as measured by the IF test for the IgG and IgM antibody classes. The effects of the antimonial therapy on the levels of specific circulating antibodies were also investigated. 
Identification of a correlation between clinical findings and the results of serological tests may improve the interpretation of these tests for diagnostic and prognostic purposes in human leishmaniasis.

\section{MATERIALS AND METHODS}

Two hundred fourteen cases of American cutaneous leishmaniasis (ACL), from the endemic area of Jacarepaguá and its surrounding, in the municipality of Rio de Janeiro, were studied.

The patients were examined and treated at the Vargem Grande Health Unit, located in the endemic area, during the period from January, 1981 to February, 1987. All cases were studied during the period of activity of the lesions. The diagnosis was established by clinical, epidemiological, parasitological and immunological criteria.

Parasitological diagnosis was performed on material from biopsies of the cutaneous lesions, using the following methods: a) printing on slides stained with Giemsa; $b$ ) culturing in NNN medium enriched with RPMI 1640 (Sigma, USA) and c) histopathological examination of slides stained with hematoxylin-eosine or Giemsa.

Immunological diagnosis was based on Montenegro's skin test (MST), using Leishmania promastigote antigen preparation containing 40 ug of $\mathrm{N} / \mathrm{ml}$ (Melo et al., 1977), supplied by the "Superintendencia de Campanhas de Saúde Pública" (SUCAM), and on the indirect immunofluorescence serological test for anti-Leishmania antibodies of the IgG and IgM classes (IF-IgG and IF-IgM), according to Camargo \& Rebonato (1969), Coutinho et al. (1970), and Marzochi et al. (1980).

The MST was considered as positive when displaying an enduration of five millimeters or more in its larger diameter, 48 hours after inoculation. Promastigotes of the MHOM/BR/ 76/JOF strain, isolated from a human case of $\mathrm{ACL}$ in the Rio Doce Vallery area (Minas Gerais), and characterized as similar to $L$. major (Momen et al., 1985) were used as source of antigens for the immunofluorescent test. Previous observations in our laboratory have shown that the use of this strain as antigen produces titers higher than those obtained with other strains, including those with the local strain of $L . b$. brasiliensis (unpublished data). Titers of 45 or more were considered as positive.

The 214 cases were distributed as follows: 121 subjects were male, 93 female. As regards age, 50 were from 0 to 9 years old; 57 from 10 to $19 ; 41$ from 20 to $29 ; 24$ from 30 to $39 ; 19$ from 40 to $49 ; 11$ from 50 to 59 , and 12 were sixty years of age or older.

Patients were treated by daily intramuscular injections of pentavalent antimonial (GLUCANTIME), supplied by SUCAM, in doses of $60 \mathrm{mg} /$ $\mathrm{kg} /$ day, in three series of ten days each, with ten day intervals between each series.

Sera from 28 individuals (named group 1) out of the 214 patients with cutaneous leishmaniasis were tested by means of IF-IgG and IF$\operatorname{IgM}$, prior (one day before the onset of the treatment), during (at the end of the second or third series) and after (one week after the last injection of the third series) the antimonial therapy. The results of group 1 obtained before the antimonial therapy were compared to those of two groups of healthy subjects: group 2 (28 individuals with positive MST: 20 of them with a previous history of $\mathrm{ACL}$, presenting suggestive scars and eight of them without previous history of ACL) and group 3 (29 individuals with negative MST). Groups 2 and 3 were composed of individuals residing in the same homes with individuals of group 1 or in neighboring homes where cases of cutaneous leishmaniasis had occurred. Groups 1,2 and 3 displayed similar distribution as regards to age, sex, occupation and socioeconomic conditions.

Apart from the 214 cutaneous leishmaniasis patients referred to, other groups of patients were studied for the comparison between the humoral immune responses present in different clinical forms of leishmaniasis, namely: four individuals from the endemic Jacarepagua area, bearing active lesions of mucosal leishmaniasis and 16 individuals with American visceral leishmaniasis (AVL), from other areas in the periphery of the city of Rio de Janeiro (Marzochi et al., 1985).

The IF-IgG and IF-IgM results of the various groups studied were compared in terms of the means of the logarithms of the titers using the analysis of variance and the Student's " $T$ " test. 


\section{RESULTS}

The distribution of the IF-IgG and IF-IgM titers of 214 patients with active cutaneous lesions and of four patients with active mucosal lesions of American mucocutaneous leishmaniasis (AML), all from the endemic area of Jacarepaguá and surroundings, is shown in Table 1. During the period of this study, only four cases with mucosal lesions were diagnosed in this area.

The 214 patients with the cutaneous form were classified into groups according to the duration and the number of lesions.

According to the duration of the cutaneous lesions they were classified into two groups: one with less than four months and one with four or more months of disease. A comparsion of the means of the logarithms of the IF-IgG and IF-IgM titers in these two groups showed that the IF-IgM titers in the group with shorter periods of disease progression were significantly higher $(p<0.05)$ than those of the group with longer periods (Table II). No difference was observed between the two groups as regards IF-IgG.

TABLE I

Distribution of anti-Leishmania antibody titers ( $\operatorname{lgG}$ and $\operatorname{lgM})$ as measured by the indirect immunofluorescence test ( $\mathrm{F}$ ) in sera from cutaneous (CL) and mucocutaneous (ML) leishmaniasis patients

\begin{tabular}{|c|c|c|c|c|c|c|c|c|c|}
\hline \multirow{2}{*}{$\begin{array}{l}\text { Clinical } \\
\text { form }\end{array}$} & \multirow{2}{*}{ Ig class } & \multicolumn{6}{|c|}{ IF titers } & \multirow{2}{*}{$\begin{array}{c}\text { Total } \\
\text { number } \\
\text { of patients }\end{array}$} & \multirow{2}{*}{ Positivit } \\
\hline & & NR & 45 & 90 & 180 & 360 & 720 & & \\
\hline \multirow{2}{*}{ CL } & IgG & $\begin{array}{c}94 \\
(43.9 \%)\end{array}$ & $\begin{array}{c}54 \\
(25.2 \%)\end{array}$ & $\begin{array}{c}36 \\
(16.8 \%)\end{array}$ & $\begin{array}{c}16 \\
(7.5 \%)\end{array}$ & $\begin{array}{c}10 \\
(4.7 \%)\end{array}$ & $\begin{array}{c}4 \\
(1.9 \%)\end{array}$ & $\begin{array}{c}214 \\
(100 \%)\end{array}$ & $56.1 \%$ \\
\hline & $\operatorname{IgM}$ & $\begin{array}{c}182 \\
(85.0 \%)\end{array}$ & $\begin{array}{c}18 \\
(8.4 \%)\end{array}$ & $\begin{array}{c}13 \\
(6.1 \%)\end{array}$ & - & $\begin{array}{c}1 \\
(0.5 \%)\end{array}$ & - & $\begin{array}{c}214 \\
(100 \%)\end{array}$ & $15 \%$ \\
\hline \multirow{2}{*}{ ML } & IgG & - & - & $(25.0 \%)$ & $\begin{array}{c}1 \\
(25.0 \%)\end{array}$ & $\begin{array}{c}2 \\
(50.0 \%)\end{array}$ & - & $\begin{array}{c}4 \\
(100 \%)\end{array}$ & $100 \%$ \\
\hline & $\lg M$ & $\begin{array}{c}2 \\
(50.0 \%)\end{array}$ & - & $\begin{array}{c}2 \\
(50.0 \%)\end{array}$ & - & - & - & $\begin{array}{c}4 \\
(100 \%)\end{array}$ & $50 \%$ \\
\hline
\end{tabular}

$\mathrm{NR}=$ non-reactive at $1: 45$ dilution.

TABLE II

Distribution of anti-Leishmania $\mathrm{IgM}$ antibody titers as measured by the indirect immunofluorescence test (IF) in sera of cutaneous leishmaniasis patients according to the duration of the disease

\begin{tabular}{|c|c|c|c|c|c|c|c|}
\hline \multirow{2}{*}{$\begin{array}{l}\text { Duration of } \\
\text { the disease }\end{array}$} & \multicolumn{5}{|c|}{ IF-IgM titers } & \multirow{2}{*}{$\begin{array}{c}\text { Total } \\
\text { number } \\
\text { of patients }\end{array}$} & \multirow{2}{*}{$\overline{\mathrm{X}} \log$} \\
\hline & NR & 45 & 90 & 180 & 360 & & \\
\hline$<4$ months & $\begin{array}{c}142 \\
(83.0 \%)\end{array}$ & $\begin{array}{c}15 \\
(8.8 \%)\end{array}$ & $\begin{array}{c}13 \\
(7.6 \%)\end{array}$ & - & $\begin{array}{c}1 \\
(0.6 \%)\end{array}$ & $\begin{array}{c}171 \\
(100 \%)\end{array}$ & $0.309^{*}$ \\
\hline$\geqslant 4$ months & $\begin{array}{c}40 \\
(93.0 \%)\end{array}$ & $\begin{array}{c}3 \\
(7.0 \%)\end{array}$ & - & - & - & $\begin{array}{c}43 \\
(100 \%)\end{array}$ & $0.115^{*}$ \\
\hline
\end{tabular}

$\mathrm{NR}=$ non-reactive at $1: 45$ dilution.

$\overline{\mathrm{X}} \log =$ mean of the logarithms of the antibody titers.

$* \quad=$ significantly different $(p<0.05)$. 
With regard to the number of lesions, the 214 patients were also classified into two groups, those with a single lesion and those with more than one lesion. A comparison between the means of the logarithms of the IF-IgG and IF-IgM titers of these two groups showed that the patients with multiple lesions displayed IF-IgG levels significantly higher $(\mathrm{p}<0.05)$ than the patients with a single lesion (Table III). There was no difference between these two groups as to the IF-IgM titers.

Figs 1 and 2 show, respectively, the distribution of the IF-IgG and IF-IgM titers of the following groups of individuals: a) the 214 patients with active lesions of American cutaneous leishmaniasis; b) 71 patients, within the group of 214 , in which the presence of Leishmania was detected in material from biopsies of the lesions; c) 38 patients, out of the 214, in which Leishmania was not observed in the parasitological examinations; and d) 16 patients with $\mathrm{AVL}$, who came from other areas.

The titers of IF-IgG and IF-IgM in the group with visceral leishmaniasis were significantly higher than those of the 214 patients with cutaneous leishmaniasis $(p<0.005)$. Amongst the patients with $\mathrm{ACL}$, parasitologically positive patients had IgG and IgM titer distribution equivalent to that of parasitologically negative patients.

To check whether or not the indirect immunofluorescence test was capable of singling out the patients with active ACL from the individuals without active lesions, a study was made of three groups of individuals from the same localities in the endemic area, with similar characteristics regarding sex, age, occupation and socioeconomic level: group 1 (28 patients with active ACL), group 2 (28 healthy individuals with positive MST) and group 3 (29 healthy individuals with negative MST).

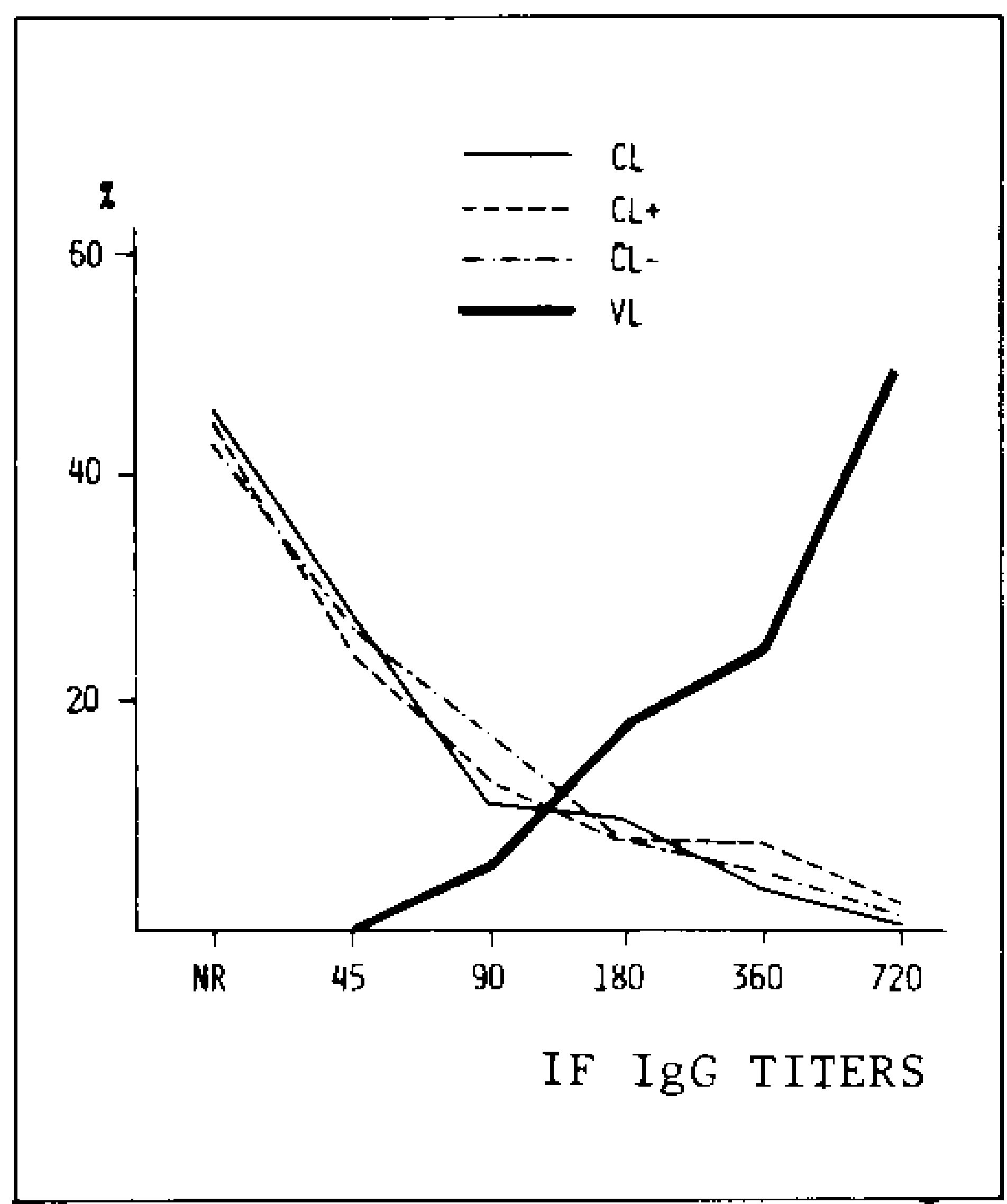

Fig. 1: distribution of anti-Leishmania IgG antibody titers as measured by the indirect immunofluorescence test (IF-IgG) in sera from 214 cutaneous leishmaniasis patients (CL), 71 cutaneous leishmaniasis patients with Leishmania found in material from lesion biopsies $(\mathrm{CL}+), 38$ cutaneous leishmaniasis patients from whom Leishmania was not detected in material from lesion biopsies (CL-) and 16 visceral leishmaniasis patients (VL). Sera were considered as nonreactive (NR) when negative at a 1:45 dilution.

\section{TABLE III}

Distribution of anti-Leishmania IgG antibody titers as measured by the indirect immunofluorescence test (IF) in sera from cutaneous leishmaniasis patien ts according to the number of lesions

\begin{tabular}{ccccccccc}
\hline \multirow{2}{*}{$\begin{array}{c}\text { Number } \\
\text { of lesions }\end{array}$} & \multicolumn{9}{c}{ IF-IgG titcrs } & \multicolumn{3}{c}{$\begin{array}{c}\text { Total } \\
\text { NR }\end{array}$} & 45 & 90 & 180 & 360 & 720 & $\begin{array}{c}\text { number } \\
\text { of patients }\end{array}$ & $\bar{X} \log$ \\
\hline 1 & 81 & 41 & 28 & 11 & 7 & 3 & 171 & $1.016^{*}$ \\
& $(47.4 \%)$ & $(24.0 \%)$ & $(16.4 \%)$ & $(6.4 \%)$ & $(4.1 \%)$ & $(1.7 \%)$ & $(100 \%)$ & \\
$>1$ & 13 & 13 & 8 & 5 & 3 & 1 & 43 & $1.370^{*}$ \\
& $(30.2 \%)$ & $(30.2 \%)$ & $(18.6 \%)$ & $(11.6 \%)$ & $(7.0 \%)$ & $(2.3 \%)$ & $(100 \%)$ & \\
\hline
\end{tabular}

$\mathrm{NR}=$ non-reactive at $1: 45$ dilution.

$\overline{\mathrm{X}} \log =$ mean of the logarithms of the antibody titers.

$* \quad=$ significantly different $(\mathrm{p}<0.05)$. 


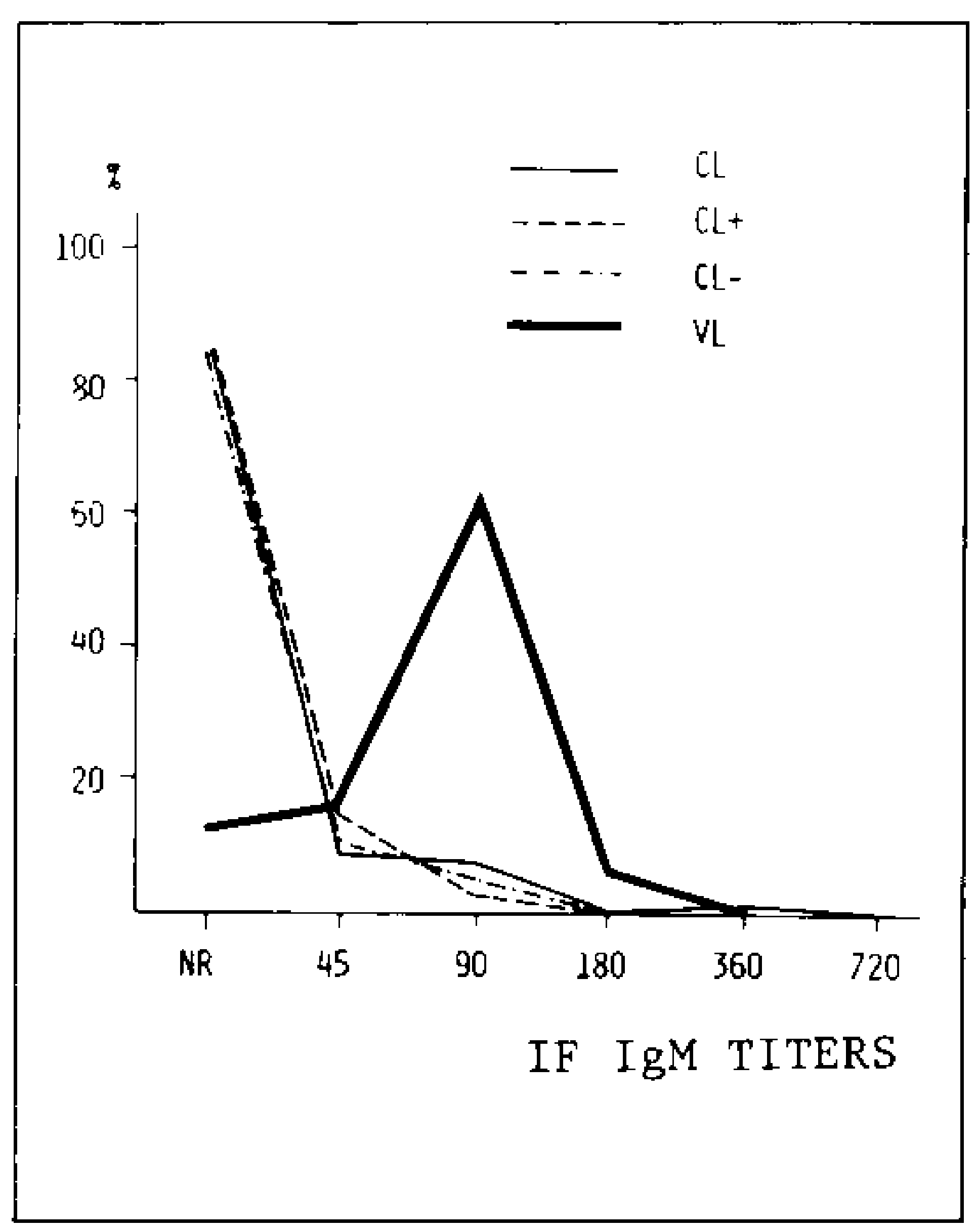

Fig. 2: distribution of anti-Leishmania IgM antibody titers as measured by the indirect immunofluorescence test (IF) in sera from 214 cutaneous leishmaniasis patients (CL), 71 cutaneous leishmaniasis patients with Leishmania found in material from lesions biopsies (CL+), 38 cutaneous leishmaniasis patients from whom Leishmania was not detected in material from lesion biopsies (CL-) and 16 visceral leishmaniasis patients (VL). Sera were considered as nonreactive (NR) when negative at a 1:45 dilution.
The distribution of the IF-IgG titers in these three groups are depicted in Table IV and in Fig. 3. The mean of the IF-IgG titers of group 1 , prior to the antimonial treatment, was significantly higher that the means of groups 2 and $3(p<0.001)$, which did not differ from each other.

The IF-IgM in these same groups of individuals displayed only six positive titers, all in the group with active disease (group 1): three individuals were reactive to a dilution of $1: 45$, two to that of $1: 90$ and one to a dilution of $1: 360$.

To study the influence of the antimonial treatment on the levels of specific antibodies, the same 28 patients of group 1 were tested with IF-IgG and IF-IgM before, during and after the application of this therapy (Table V, Fig. 3).

The mean of the logarithms of the IF-IgG titers during the antimonial treatment was significantly higher than the mean after therapy $(\mathrm{p}<0.01)$. No significant difference was found between the IF-IgG titers before and during therapy as well as between the IF-IgG titers before and after therapy. As regards the IF-IgM, the positive titers, encountered in six cases and reported in detail in the comparison between groups 1,2 and 3 , occurred only before the onset of the antimonial treatment.

\section{TABLE IV}

Distribution of anti-Leishmania IgG antibody titers as measured by the indirect immunofluorescence test (IF) in sera from cutaneous leishmaniasis (CL) patients with active lesions (group 1), healthy subjects with positive Montenegro skin test (MST +, group 2) and healthy subjects with negative Montenegro skin test (MST -, group 3)

\begin{tabular}{|c|c|c|c|c|c|c|c|c|}
\hline \multirow{2}{*}{ Groups } & \multicolumn{6}{|c|}{ IF-IgG titers } & \multirow{2}{*}{ Total } & \multirow{2}{*}{$\bar{X} \log$} \\
\hline & NR & 45 & 90 & 180 & 360 & 720 & & \\
\hline 1 (CL patients) & $\begin{array}{c}8 \\
(28.6 \%)\end{array}$ & $\begin{array}{c}12 \\
(42.8 \%)\end{array}$ & $\begin{array}{c}4 \\
(14.3 \%)\end{array}$ & $\begin{array}{c}3 \\
(10.7 \%)\end{array}$ & - & $\begin{array}{c}1 \\
(3.6 \%)\end{array}$ & $\begin{array}{c}28 \\
(100 \%)\end{array}$ & $1.33^{*}$ \\
\hline $2(\mathrm{MST}+)$ & $\begin{array}{c}26 \\
(92.9 \%)\end{array}$ & $\begin{array}{c}2 \\
(7.1 \%)\end{array}$ & - & - & - & - & $\begin{array}{c}28 \\
(100 \%)\end{array}$ & 0.12 * \\
\hline $3($ MST -$)$ & $\begin{array}{c}25 \\
(86.2 \%)\end{array}$ & $\begin{array}{c}3 \\
(10.3 \%)\end{array}$ & $\begin{array}{c}1 \\
(3.5 \%)\end{array}$ & - & - & - & $\begin{array}{c}29 \\
(100 \%)\end{array}$ & $0.24 *$ \\
\hline
\end{tabular}

$\mathrm{NR}=$ non-reactive at $1: 45$ dilution.

$\overline{\mathrm{X}} \log =$ mean of the logarithms of the antibody titers.

* $\quad=$ mean of group 1 was significantly different from mean of group $2(p<0.001)$ and from mean of group $3(p<0.001)$. 
TABLE V

Distribution of anti-Leishmania $\mathrm{IgG}$ antibody titers as measured by the indirect immunofluorescence test (IF) in sera from 28 cutaneous leishmaniasis patients before, during and after antimonial therapy

\begin{tabular}{|c|c|c|c|c|c|c|c|}
\hline \multirow{2}{*}{ Time points } & \multicolumn{6}{|c|}{ 1F-IgG titers } & \multirow{2}{*}{$\overline{\mathrm{X}} \log$} \\
\hline & NR & 45 & 90 & 180 & 360 & 720 & \\
\hline before & $\begin{array}{c}8 \\
(28.6 \%)\end{array}$ & $\begin{array}{c}12 \\
(42.8 \%)\end{array}$ & $\begin{array}{c}4 \\
(14.3 \%)\end{array}$ & $\begin{array}{c}3 \\
(10.7 \%)\end{array}$ & - & $\begin{array}{c}1 \\
(3.6 \%)\end{array}$ & $1.33^{*}$ \\
\hline during & $\begin{array}{c}4 \\
(14.3 \%)\end{array}$ & $\begin{array}{c}13 \\
(46.4 \%)\end{array}$ & $\begin{array}{c}7 \\
(25.0 \%)\end{array}$ & $\begin{array}{c}4 \\
(14.3 \%)\end{array}$ & - & - & $1.58^{*}$ \\
\hline after antimonial therapy & $\begin{array}{c}14 \\
(50.0 \%)\end{array}$ & $\begin{array}{c}7 \\
(25.0 \%)\end{array}$ & $\begin{array}{c}5 \\
(17.9 \%)\end{array}$ & $\begin{array}{c}2 \\
(7.1 \%)\end{array}$ & - & - & $0.92 *$ \\
\hline
\end{tabular}

$\mathrm{NR}=$ non-reactive at $1: 45$ dilution.

$\overline{\mathbf{X}} \log =$ mean of the logarithms of the antibody titers.

${ }^{*}=$ significantly different $(p<0.01)$.

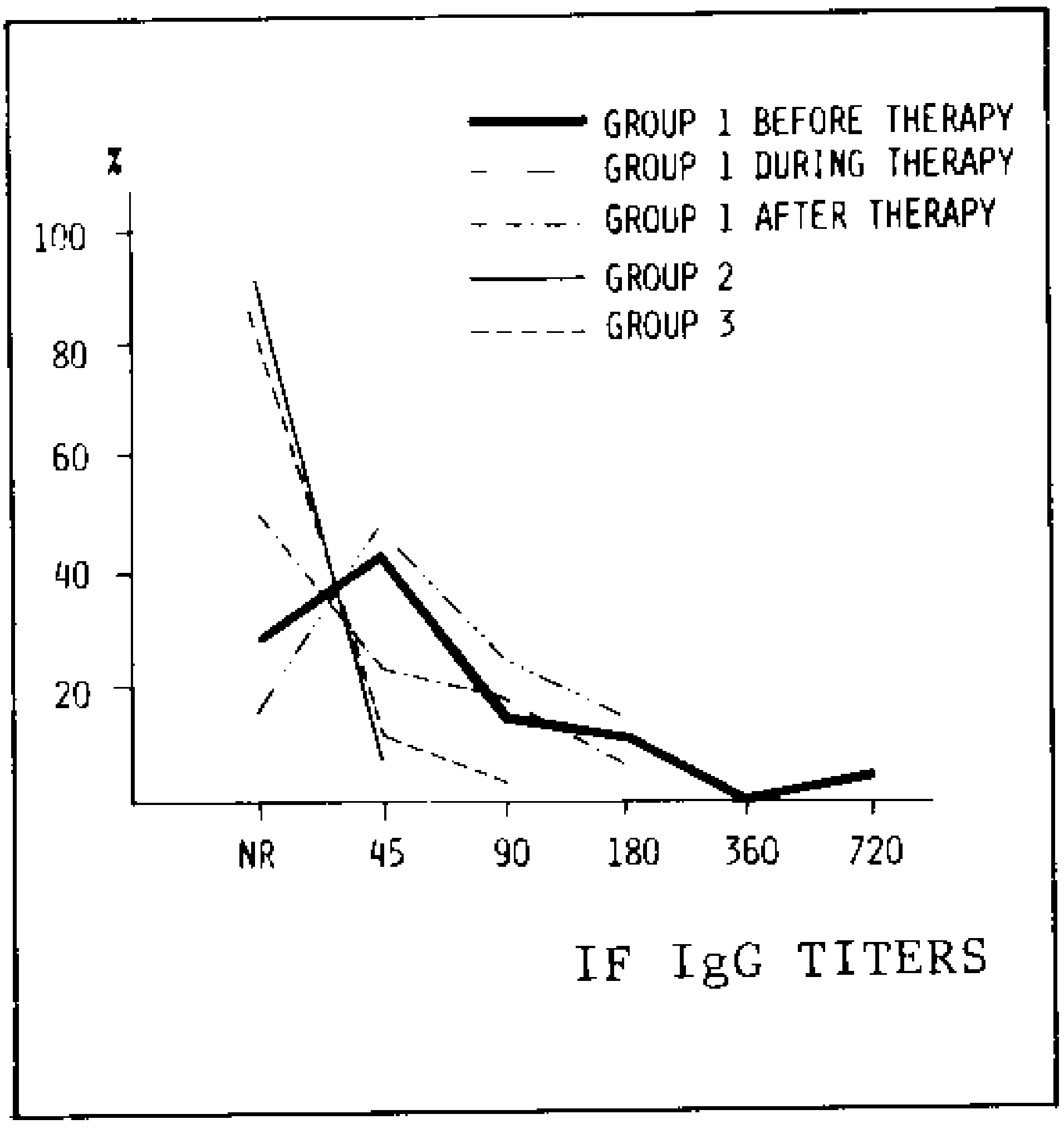

Fig. 3: distribution of anti-Leishmania IgG antibody titers as measured by the indirect immunofluorescence test in sera from 28 cutaneous leishmaniasis patients (group 1) before, during and after antimonial therapy, 28 healthy subjects with positive Montenegro's skin test (group 2) and 29 healthy subjects who did not react to the Montenegro's skin test (group 3). Sera were considered as non-reactive (NR) when negative at a $1: 45$ dilution.

\section{DISCUSSION}

The indirect immunofluorescence reaction was initially proposed for diagnosis and subsequently for the control of cure of ACL. Use of the test as a means of diagnosis is impaired in the areas where other endemic diseases coexist, such as visceral leishmaniasis and Chagas' disease, on account of the frequent crossreactivity (Furtado, 1980). However, in the Jacarepaguá area, these diseases are not endemic.

The subspecies $L . \quad b$. braziliensis has been indicated as the principal etiological agent of the mucocutaneous form of ACL (Lainson \& Shaw, 1972) In the Jacarepaguá area, however, where the disease has long been present at endemic levels, and where L. b. b. alone has been identified in isolates from human and canine lesions, this clinical form is not frequent. In the rare cases in which mucosal lesions are observed, there are no signs that those lesions are secondary metastatic. They are generally due to spreading of facial cutaneous lesions to contiguous oral, nasal or ocular mucous membranes.

The low frequency of mucosal lesions observed in the Jacarepagua area contrasts with observations made in other areas of $\mathbf{L}$. b. b. transmission (Cuba et al., 1984). This may be due to the low virulence of the local strain or to the fact that treatment was generally applied at an early stage, since the majority of the lesions observed had undergone short periods of evolution in the present series of patients (Table II).

Although the small number of cases with mucosal lesions made it impossible to effect a statistical analysis, it may be seen from Table I that these individuals displayed relatively high titers of specific antibodies as measured by 
indirect immunofluorescence. They all had positive IF-IgG titers, whereas amongst the 214 patients with exclusively cutaneous lesions only $56.1 \%$ were positive.

It was noted that patients with shorter periods of evolution of the cutaneous lesions (less than 4 months) displayed IF-IgM titers significantly higher than those of patients with longer periods. This test was only $7.0 \%$ positive amongst patients with a period of evolution of four months or more, whereas amongst the patients with less than four months of disease the positivity of IF-IgM was $17.0 \%$. Furthermore, all the positive IF-IgM titers found in the groups with longer periods of evolution (five months or more) were low (not higher than 45) while IF-IgM titers of 90 or higher were found in $8.2 \%$ of the patients with less than four months of disease. These results suggest that IF-IgM titers higher or equal to 90 are indicative of early stages of ACL. This datum may be useful for epidemiological and clinical purposes, specially when the patient is not able to inform the precise duration of the lesions (e. g. psychotic patients). From the clinical point of view, there is evidence that the duration of the cutaneous lesions may be important for prognosis, since some authors have found an association between long duration of cutaneous lesions (more than one year) and higher incidence of mucosal lesions (Pessoa, 1941; Marsden, 1986).

As regards IF-IgG, although no association with the time of evolution of the lesions was encountered: it was observed that individuals with more than one lesion displayed titers significantly higher than those of the individuals with only a single lesion. Similar results had already been reported by other researchers (Chiari, 1971; Chiari et al., 1973a; Cuba et al., 1980). The presence of higher levels of specific antibodies in patients with multiple lesions may be due to the higher load of parasitic antigens which in these cases would be capable of sensitizing a larger number of specific lymphocytes. Alternatively, multiple lesions may, in some cases, be generated by dissemination of the infection, which either by the lymphatic or hematogenic route would probably afford greater chance of interaction between parasitic antigens and the cells of the immune system that are capable of recognizing them, thus resulting in higher levels of humoral response. From the results shown, one can suppose that the presence of higher titers of specific antibodies reflects the invasive character of the infection. The fact that the patients with visceral leishmaniasis displayed titers significantly higher than those of the patients with cutaneous leishmaniasis supports this hypothesis.

Besides this, some authors have encountered higher indices of positivity or higher titers in patients with mucosal lesions (Convit \& Pinardi, 1969; Guimarāes et al., 1969; Cuba et al., 1984) than in patients with exclusively cutaneous lesions, although those observations were not confirmed by others (Chiari et al., 1973a; Shaw \& Lainson, 1977). The pathogenesis of mucosal lesions is not yet clearly understood. Such studies have been greatly impaired by the non-avaiability of an experimental model capable of reproducing the features of human mucocutaneous leishmaniasis. The longstanding survival of parasites as well as the development of a hypersensitivity state may be involved in the generation of high titers of specific antibodies. However, it is not clear whether the exacerbated cellular (Castes et al., 1983; 1984; Carvalho et al., 1985) and humoral immune responses found in those patients are a cause or a consequence of the particular hostparasite relationship that produces the mucosal lesions.

Amongst the cases studied here with active cutaneous leishmaniasis, the individuals in which Leishmania was found in the lesions had IF-IgG and IF-IgM titers similar to those of the patients in which the parasitological examinations were negative. These results indicate that these serological tests may contribute to diagnosis in cases in which it was not possible to encounter parasites.

The indirect immunofluorescence test proved capable of singling out individuals with active lesions of cutaneous leishmaniasis, since the group of patients with active ACL displayed IF-IgG titers significantly higher than those of the groups of healthy individuals residing in the endemic area. The IF-IgG in the group of 28 healthy individuals with positive MST, most of whom had a previous record of ACL, displayed only $7.1 \%$ of positivity, as opposed to $71.4 \%$ of positivity encountered in the group of 28 patients with active ACL. These results point to the usefulness of this method for controlling the cure of this parasitosis. It was also observed 
in this study that the IF-IgG titers of patients with ACL were significantly lower one week after the end of the antimonial treatment than during the treatment. This indicates that as soon as the lesions starts to heal the levels of specific $\operatorname{IgG}$ begin to decline. This observation reinforces the importance of the serological follow-up for the prognosis of the cases under treatment and its usefulness as one more parameter, besides clinical examination for orienting the criteria of cure (Chiari et al., 1973b; Souza et al., 1982). The absence of significant difference between the IF-IgG titers before and after therapy may be due to the very early examination of the patients after therapy.

The IF-IgM, despite its low positivity, also proved to be useful for diagnosis, since only individuals with active disease had positive titers by this method.

\section{RESUMO}

Reação de imunofluorescência indireta nas leishmanioses do Novo Mundo: relações entre aspectos clínicos e sorológicos - $\mathrm{O}$ teste de imunofluorescência indireta (IF) para a detecção de anticorpos anti-Leishmania nas classes $\operatorname{IgG}$ e IgM foi realizado em soros de indivíduos dos seguintes grupos: 214 pacientes com leishmaniose cutânea, quatro pacientes com leishmaniose mucocutânea, 28 indivíduos sadios com intradermorreação de Montenegro (IDRM) positiva, 29 indivíduos sadios com IDRM negativa e 16 pacientes com leishmaniose visceral. Os indivíduos dos quatro primeiros grupos eram provenientes de uma área da periferia da cidade do Rio de Janeiro (Jacarepaguá) onde a leishmaniose tegumentar causada por Leishmania braziliensis braziliensis é endêmica.

Entre os pacientes com leishmaniose cutânea foi observado que os títulos de IF-IgM foram significantemente mais altos nos casos com menos de quatro meses de evolução do que em pacientes com períodos mais longos de evolução da doença $c$ que os títulos de IF-IgG foram significantemente mais altos em pacientes com lesões múltiplas do que nos portadores de lesão única. Os pacientes com leishmaniose visceral tiveram títulos de IF-IgG significantemente superiores aos dos pacientes com leishmaniose cutânea.

Um grupo de 28 indivíduos selecionados entre os 214 pacientes com leishmaniose cutânea tiveram seus títulos de IF (IgG e IgM) comparados aos de dois grupos controles constituídos de indivíduos sadios, moradores na área endêmica com IDRM respectivamente positiva e negativa. Títulos de IF-IgG e IF-IgM significantemente superiores foram encontrados no grupo com doença ativa. O mesmo grupo de pacientes apresentou títulos de IF-IgG significantemente mais baixos após a terapêtica antimonial do que durante a mesma.

Palavras-chave: leishmanioses americanas - sorologia imunofluorescência

\section{ACKNOWLEDGEMENTS}

We greatefully acknowledge Mr Belmiro de Mello for invaluable help at the Vargem Grande Health Unit, Mr Gentil Dutra for expert technical assistance, Ms Rosangela Pelegrino for excellent secretarial assistance and Dr Hooman Momem for reading the manuscript.

\section{REFERENCES}

BITTENCOURT, A. C.; SODRE, A. \& ANDRADE, Z. A., 1968. Pesquisa de anticorpos circulantes pelo método de imunofluorescência na leishmaniose tegumentar. Rev. Inst. Med. trop. Sāo Paulo, 10: $247-252$.

CAMARGO, M. E. \& REBONATO, C., 1969. Cross reactivity in fluorescence tests for Trypanosoma and Leishmania antibodies. Am. J. Trop. Med. Hyg., 18:500-505.

CARVALHO, E. M.; JOHNSON, W. D.; BARRETO, E.; MARSDEN, P. D.; COSTA, J. L. M.; REED, S. \& ROCHA, H., 1985. Cell mediated immunity in American cutaneous and mucosal leishmaniasis. J. Immunol, 135: 4144-4149.

CASTES, M.; AGNELLI, A.; VERDE, O. \& RONDON, A. J., 1983. Characterization of the cellular immune response in American cutaneous leishmaniasis. Clin. Immunol. Immunopathol., 27: 176186.

CASTES, M.; AGNELLI, A. \& RONDON, A. J., 1984. Mechanisms associated with immunoregulation in human American cutaneous leishmaniasis. Clin. exp. Immunol, 57:279-286.

CHIARI, C. A., 1971. Pesquisa de anticorpos circulantes na leishmaniose tegumentar americana pela reaçầo de imunofluorescência indireta. Master Thesis. Departamento de Zoologia e Parasitologia do Instituto de Ciências Biológicas da Universidade Federal de Minas Gerais, Belo Horizonte, $64 \mathrm{p}$.

CHIARI, C. A.; MAGALHÄES, P. A. \& MAYRINK, W., 1973a. Pesquisa de anticorpos, por imunofluorescência, em soros de pacientes com leishmaniose tegumentar americana apresentando lesōes cu tàneas recentes. Rev. Inst. Med. trop. São Paulo, 15: 304-309.

CHIIARI, C. A.; MAYRINK, W. \& MAGALHĀES, P. A, , 1973b. Reação de imunofluorescência indireta no controle de tratamento da lcishmaniose tegumentar americana. Rev. Inst. Med. trop. Säo Paulo, 15:298-303 
CONVIT, J. \& PINARDI, M. E., 1969. Applying the indirect immunofluorescence test to the study of American cutaneous leishmaniasis. Derm. Inter., $8: 17-20$.

COUTINHO, S. G.; ANDRADL, C. M.; MALVAR, G. S. \& I'ERREIRA, L. F., 1970. Análise comparativa entre as sensibilidades da reação indireta de anticorpos fluorescentes e da reaçāo de SabinFeldman na pesquisa de anticorpos séricos para toxoplasmose. Rev. Soc. Bras. Med. trop., 4: 315-325.

COUTINHO, S. G.; NUNES, M. P.; MARZOCHI, M. C. A. \& TRAMONTANO, N., 1985. A survey for American cutaneous and visceral leishmaniasis among 1342 dogs from areas in Rio de Janeiro (Brazil) where the human diseases occur. Mem. Inst. Oswaldo Cruz, 80:17-22.

CUBA, C. C.; LLANOS-CUENTAS, E. A.; BARRETO, A. C.; MAGALHÃES, A. V.; LAGO, E. L.; REED, S. G. \& MARSDEN, P. D., 1984. Human mucocutaneous leishmaniasis in Três Braços, Bahia Brazil. An area of Leishmania braziliensis brazi. liensis transmission. 1. Laboratory Diagnosis. Rev. Soc. Bras. Med. Trop., 17:161-167.

CUBA, C. A. C.; MARSDEN, P. D.; BARRETO, A. C.; ROCHA, R.; SAMPAIO, R. R. \& PATZLAFF, L., 1980. Diagnóstico parasitológico e imunológico da leishmaniasis tegumentaria americana. Bol. Of. Sanit. Panam., 89: 195-206.

D'UTRA e SILVA, O., 1915. Sobre a leishmaniose tegumentar e seu tratamento. Mem. Inst. Oswaldo Cruz, 7: 213-241.

FURTADO, T., 1980. Critérios para o diagnóstico da leishmaniose tegumentar americana. An. Bras. Dermatol., 65: 81-86.

GRIMALDI Jr., G.; DAVID, J. R. \& McMAHON PRATT, D., 1987. Identification and distribution of New World Leishmania species characterized by serodeme analysis using monoclonal antibodies. Am. J. Trop. Med. Hyg., 36: 270-287.

GUIMARĀES, N. F.; LAGE, H. A.; VENANCIO, I. A. \& GRYNBERG, N. F., 1969. Estudo comparativo da reação indireta de anticorpos fluorescentes em doença de Chagas, leishmanioses tegumentares e calazar com vários antígenos de "Leishmania" e "Trypanosoma". O Hospital, 75: 299-313.

LAINSON, R. \& SHAW, J. J., 1972. Leishmaniasis of the New World: Taxonomic problems. Brit. med. Bull., 28:44-48.

LOPLS, U. C.; MOMEN, H.; GRIMALDI Jr., G.; MARZOCHI, M. C. A.; PACHECO, R. S. \& MOREL, C. M., 1984. Schizodeme and zymodeme characterization of Leishmania in the investigation of foci of visceral and cutaneous leishmaniasis. J. Parasitol, 70:89-98.

MARSDEN, P. D., 1986. Mucosal leishmaniasis ("espundia" Escomel, 1911). Trans. R. Soc. Trop. Med. Hyg., 80: 859-876.

MARZOCHI, M. C. A.; COUTINHO, S. G.; SABROZA, P. C. \& SOUZA, W. J. S., 1980. Reação de imunofluorescência indireta e intradermorreação para leishmaniose tegumentar americana em moradores na área de Jacarepaguá (Rio de Janeiro). Estudo comparativo dos resultados observados em 1974 e 1978. Rev. Inst. Med. trop. Säo Paulo, 22: 149-155

MARZOCHI, M. C. A.; SABROZA, P. C.; TOLEDO, L. M.; MARZOCHI, K. B. F.; TRAMONTANO, N. C. \& RANGEL FILHO, F. B., 1985. Leishmaniose visceral na cidade do Rio de Janeiro, Brasil. Cadernos de Saúde Pública, RJ, 1:432-446.

MELO, M. N.; MAYRINK, W.; COSTA, C. A., MAGALHÃES, P. A.; DIAS, M.; WILLIAMS, P.; ARAÜJO, F. G.; COELHO, M. V. \& BATISTA, M., 1977. Padronização do antígeno de Montenegro. Rev. Inst. Med. trop. Säo Paulo, 19: 161-164.

MOMEN, H.; GRIMALDI Jr. G.; PACHECO, R. S.; JAFFE, C. L.; McMAHON-PRATT, D. \& MARZOCHI, M. C. A., 1985. Brazilian Leishmania stocks phenoty pically similar to $L$. maior. Amer. J. Trop. Med. Hyg., 34: 1076-1084.

ODDO, F. G. \& CASCIO, G., 1963. Il test di immunofluorescence nelle leishmaniosi viscerale c cutanea. Riv. Inst. Sierotec. Ital., 38: 139-145.

PESSOA, S. B., 1941. Dados sobre a epidemiologia da leishmaniose tegumentar em S. Paulo. O Hospital, 19:389-409.

PIRMEZ, C.; COUTINHO, S. G.; MARZOCHI, M. C. A.; NUNES, M. P. \& GRIMALDI Jr., G., 1988. Canine american cutaneous leishmaniasis: a clinical and immunological study in dogs naturally infected with Leishmania braziliensis braziliensis in an endemic area of Rio de Janeiro. Brazil. $A m$. J. Trop. Med. Hyg., 38: 52-58.

SHAW, J. J. \& LAINSON, R., 1977. A simply prepared amastigote leishmanial antigen for use in indirect fluorescent antibody test for leishmaniasis. $J$. Parasitol., 63: 384-385.

SOUZA, W. J. S.; COUTINHO, S. G.; MARZOCHI, M. C. A.; TOLEDO, L. M. \& GOTTLIEB, M. V., 1982. Utilização da reaçâo de imunofluorescência indireta no acompanhamento da terapêutica da leishmaniose tegumentar americana. Mem. Inst. Oswaldo Cruz, 77: 247-253. 